\title{
CRITICAL REFLECTIONS ON MUSIC AND HUMANITARIAN NARRATIVES
}

\author{
LUIS VELASCO-PUFLEAU \\ University of Fribourg / \\ Fondation Maison des sciences de l'homme, Paris
}

\author{
Afterword by Stephanie Weber \\ Lenbachhaus, Munich
}

\section{Introduction}

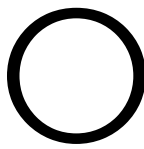
n November 16, 2014, Bob Geldof appeared on the UK TV show The X-Factor in order to present the latest version of his 1984 well-known charity song "Do They Know It's Christmas?" Recorded by several artists brought together for the Band Aid 30 project, the song was produced and slightly adapted (Jeffries 2014) with the claimed objective of fighting the Ebola virus outbreak — described by Geldof as "the most anti-human disease"-in several countries in West Africa. ${ }^{1}$ Mobilising a rhetoric of war, Geldof explained to the audience that buying a pop single can change the world since we make things together: "We go to war, we are going to stop this thing, buy the song."

Once again, Geldof was on TV shows and the news in order to talk about charity, humanitarian crises, death, and victims in far-off countries. Assuming a collective point of view, he presented himself as a legitimate "humanitarian ambassador," claiming that "for thirty years we have been dealing with humanitarian issues in Africa." In fact, Band Aid 30 was the latest and recurrent version of Band Aid, first created in 1984 with the purpose of fighting the famine caused by the 1983-1985 Ethiopian civil war, and followed by Band Aid II in 1989, and Band Aid 20 in 2004. Moreover, Band Aid was also the first of many similar projects in the so-called free world, such as USA for Africa and their song "We Are The World" in the United States, and Chanteurs sans frontières with "Chanson pour l'Éthiopie" in France. ${ }^{3}$

1 The German version of this song was released on November 26, 2014. The French version (Noël est là) was released on December 1, 2014, by the singer Carla Bruni-Sarkozy, wife of the former French President Nicolas Sarkozy. In the context of Sarkozy's contest for the Presidency of the French Party Union pour un Mouvement Populaire (UMP), on December 6, 2014, the lead role of Carla BruniSarkozy in this symbolic political dispositif had a manifest propagandistic dimension.

2 Unless otherwise indicated, all quotes come from speeches included in our work Reflections on Music and Propaganda (Velasco-Pufleau and Santamaría Borges 2017).

3 Such highly visible songs and concerts have been used to raise funds and to legitimate humanitarian action as a response to political and economic issues in most of the media covered humanitarian 


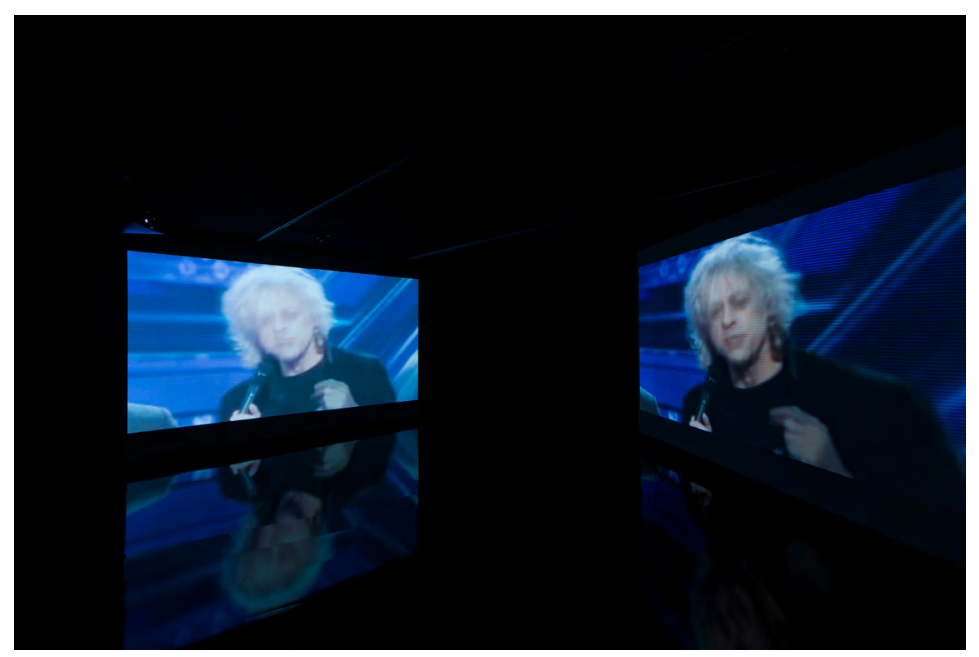

Figure 1. Bob Geldof on The X-Factor, in Luis Velasco-Pufleau and Sergio Santamaría Borges, Reflections on Music and Propaganda, 2017, Video. Städtische Galerie im Lenbachhaus und Kunstbau München. Photo: Simone Gaensheimer.

Regardless of the geopolitical context, the video clips of all of these humanitarian songs show men and women with headphones on, pressed into action by the humanitarian "emergency," singing in front of microphones in a recording studio to raise funds to rescue the victims. The media narratives were similar: faced with the unbearable suffering of victims, "we" have had the idea of doing a song for "them," for the children of this or that country. Against accusations of self-promotion and incapacity of bringing the aid to the victims, Geldof replied that "all that the pop singers can do, all they can do is to sing songs." Likewise, most of "humanitarian" singers, such as the Chanteurs sans frontières co-founder Valérie Lagrange, firm in the belief that "in the West we have enough money to stop this famine in one year," and therefore "we have to give, we have to continue the action, whatever happens, and despite all the political problems that get in the waythey don't matter-we have to give and that's it." Humanitarian songs can be seen as media-based hymns of liberal democracies, destined to bring together moral communities that are as ephemeral as they powerless, at a time when humanitarianism replaced the political ideologies of the twentieth century (Velasco Pufleau 2013:116). ${ }^{4}$

In this article, I explore how an artistic work can tackle these issues and produce knowledge that is complementary to social sciences research on humanitarianism. Through the examination of the creative process and rationality behind a recent video installation presented as a part of an exhibition on contemporary propaganda, this text reflects on the role of art in stimulating critical thinking.

catastrophes to date, including hurricane Katrina (2005), the Haitian earthquake (2010), and the Philippines Haiyan typhoon (2013).

4 This article takes up and adapts ideas previously set up in two research articles (Velasco Pufleau 2013, 2014). 


\section{Deconstructing Musical Humanitarian Narratives}

n early 2017, Stephanie Weber, curator for contemporary art at the Lenbachhaus in Munich, commissioned me to do a video piece for the exhibition After the Fact. Propaganda in the $21^{\text {st }}$ century. This atypical art exhibition explored current forms and methods of propaganda in times of post-truth politics, looking at the concept of propaganda "as a complex and potentially helpful tool of analysis and thought" (Weber and Mühling 2017:6). For several years, I was working on the complementary dimension of academic research and artistic work, and the commission from the Lenbachhaus was a great opportunity to develop this further. The result was Reflections on Music and Propaganda, a video piece I did as electroacoustic music composer with the Venezuelan video artist Sergio Santamaría Borges, which expanded and completed in a particular way my research on the role of humanitarian songs in the depoliticisation of armed conflicts and the moralisation of international relations at the end of the Cold War. ${ }^{5}$

Our artistic work started from the recognition of the emotional power of humanitarian songs and media narratives which accompanied them. We wanted to deconstruct their emotional dimension through the montage, collage, and overlapping of statements from "humanitarian" musicians, TV images that accompanied the songs, and excerpts of video clips, all of them produced between 1984 and 2014. No other material was used or added, just images, words, gestures, and sounds that were scattered in a flow of information. Our objective was to reveal the ethical contradictions and the political implications of their recurrent and redundant humanitarian narratives. In other words, the "theatrical arrangement that separates safe spectators from vulnerable others and communicates its moral message through the staging of spectacles of suffering" (Chouliaraki 2013:27).

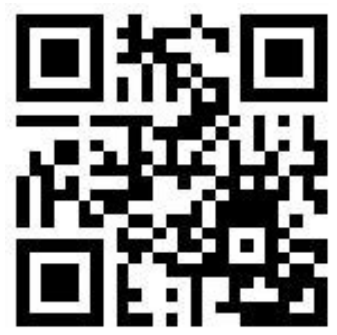

Figure 2. Luis Velasco-Pufleau and Sergio Santamaría Borges, Reflections on Music and Propaganda, 2017, Video. Commissioned by Städtische Galerie im Lenbachhaus und Kunstbau München. ${ }^{6}$

5 The title of the work is borrowed from my article "Reflections on music and propaganda" (Velasco Pufleau 2014), which at that time was being translated into German (Velasco Pufleau 2017) to be published in the exhibition book with several historical essays by Hannah Arendt, Bertolt Brecht, Edward Bernays, Jacques Ellul, and more recent thoughts by Lucy R. Lippard, Coco Fusco, and Dan Graham among others. 
We aimed to expose how in most media-centred narratives, the participants in humanitarian songs shrug off the political and ethical questions resulting from their participation. They create an impression of fraternal action which harms the historical understanding of conflicts and make difficult the establishment of sustainable political and economic solutions for the affected populations. The effectiveness of these humanitarian musical "dispositifs" is dependent on transforming political issues into moral issues, hiding the historical and geopolitical depth of the problems, and rendering the humanitarian intentions immune to attack, since they are deemed to be morally good, necessary, and urgent (Velasco-Pufleau 2014). Overall, we wanted to provide to people watching and listening to our video installation with elements to develop their critical thinking associating and dissociating the images, sounds, gestures, discourses, and staged emotions contained in the videos.

\section{From the Politics of Pity to Collective Emancipation}

$\mathrm{H}$ umanitarian songs, and TV imagery of famine and death which accompanied their video clips, victimised and misrepresented African populations. They transform the donor public's view of humanitarian action, armed conflicts, health crises, and environmental disasters from a political one to a moral one. In doing so, humanitarian songs' narratives of suffering deploy a fiction depicting the "victims" as powerless subjects of neoliberal charity, in which solidarity is "a matter of consumerist choice" (Chouliaraki 2013:188). This humanitarian individualism adopts the logic of capitalist economy, "the principles of the established 'Western' order" (Badiou 2002:5). To end suffering, all we should and can do is buy songs. As Geldof cynically asserts, "it really doesn't matter if you don't like this song ... what you have to do is buy this thing” (quoted in Jeffries 2014). In sum, humanitarian songs' narratives contributed to the development of a politics of pity cut off from social justice, as Luc Boltanski points out:

The development of a politics of pity thus assumes two classes which are not unequal by reference to merit, as in the problematic of justice, but solely by reference to luck. ... For a politics of pity, the urgency of the action needing to be taken to bring an end to the suffering invoked always prevails over considerations of justice. From such a perspective it is only in a world from which suffering has been banished that justice could enforce its rights (Boltanski 1999:5).

Humanitarian songs have enabled the development of a politics of pity in the public sphere and international relations. After the collapse of the communist regimes in the East, humanitarianism became a means of action to transform the world "here and now"

7 Michel Foucault defines the "dispositif" [apparatus] as "a thoroughly heterogeneous ensemble consisting of discourses, institutions, architectural forms, regulatory decisions, laws, administrative measure, scientific statements, philosophical, moral and philanthropic propositions-in short, the said as much as the unsaid. Such are the elements of the apparatus. The apparatus itself is the system of relations that can be established between these elements" (Foucault 1980:194). 
that would be hypothetically freed from the weight of "ideologies," while taking the place of the welfare state. Political projects of collective emancipation and social justice were replaced by ironic objectives of individual salvation and personal benefit. In 1985, Valérie Lagrange asserted on French public TV: "if out of 10 million people, 50,000 are saved, if I was one of those 50,000, I would be very happy to be one of them." ${ }^{8}$ In this dystopian worldview, politics is reduced to the number of people buying and listening to a song, as Geldof repeated without embarrassment: "if you have everybody in Germany listening to this song, thinking about it, everybody in the UK, and everybody in France, you got a lot of people, and that's political".

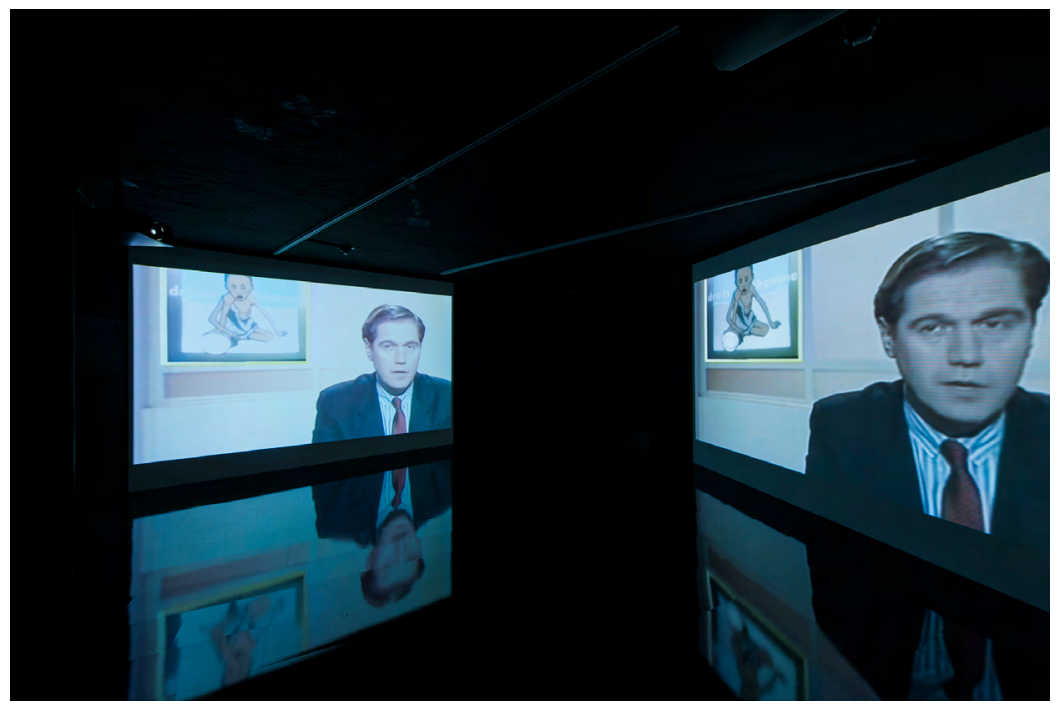

Figure 3. Reflections on Music and Propaganda. Städtische Galerie im Lenbachhaus und Kunstbau München. Photo: Simone Gaensheimer

Humanitarian musical "dispositifs" maintain the illusion that citizens can "do" something to change the world through the simulacrum of dominant media sources: donors become consumers of the poverty of others, transformed into benevolent bearers of charity through the consumerist exploitation of moralistic and consensual musical works. What kind of alternative to these narratives can we suggest? Among others, re-politicising humanitarian action and social struggles wherever they take place, focusing on a multidimensional concept of social justice which encompasses at least economic redistribution, cultural recognition, and political representation (Fraser 2008:404). Additionally, supporting and listening to political actors, musicians, and artists from countries historically concerned by humanitarian action: polemical voices which consider vulnerable others as excluded subjects of a political community, where "the excluded is a conflictual actor, an actor who includes himself as a supplementary political subject, carrying a right

8 Valérie Lagrange on French TV Antenne 2 news, July 15, 1985 (http://www.ina.fr/video/ CAB86011680). 
not yet recognized or witnessing an injustice in the existing state of right" (Rancière 2013:189). Instead of "saving our lives" through consuming disposable pop songs, we could reflect on and elaborate new forms of transnational political struggles for social justice and collective emancipation.

\section{Afterword by Stephanie Weber ${ }^{9}$}

$t$ was after a couple of months of pondering on how to actually go about this exhibition dedicated to current propaganda that we had set out to organise that I came across Luis Velasco-Pufleau's work on music and propaganda. Happening upon his text Reflections on Art and Propaganda, which should later lend its title to the video work shown at Lenbachhaus, was a crucial moment in deciding that the whole endeavor, which was just about driving us nuts, made some sense after all. The intent of the exhibition After the Fact was twofold: firstly, to depart from a political term that is heavily connoted and generally regarded as problematic in relation to art (other than say "activism") in order to think the intertwinement of art and politics from this angle, and secondly, to posit propaganda in a wider sense as a diffusive neoliberal political strategy rather than a crude and obvious rant or a thing of the past.

One of the recurrent criticisms that the exhibition has received was that we had seemingly not understood what real propaganda was since there was no mention of Putin's bot farms or the terror of ISIS. Luis Velasco-Pufleau's and Sergio Santamaría Borges's two-channel video installation exemplified the reason for which we chose to omit these and other cases of blatant propaganda. We were trying to take a look, through the lens of the works of art united for this occasion, at a specifically Western capitalist propaganda and the nationalisms and global hegemonies it has helped to bolster throughout the past decades. The video was, at first sight, a surprise to many viewers: why was it bad to raise money for starving or sick kids in Africa? But the form of the work, the ways in which the artists edited the appropriated footage into a catchy, poppy, but ultimately nauseating chain of images was self-explanatory (an important criterion for effective propaganda which the artists consciously exploited). The aesthetics of charity that humanitarian pop is relying on and that Velasco-Pufleau and Borges cast into relief in their work-images of underfed and seemingly helpless people from "Africa" filmed outdoors, juxtaposed with takes of white pop starlets in recording studios-serves to negate colonial history and political contingency in favor of an apolitical, yet deeply ideological narrative of Western generosity and philanthropy.

9 Stephanie Weber has been a curator of contemporary art at Lenbachhaus in Munich since 2014. In recent years, she has organised the exhibition, publication, and conservation project Lea Lublin: Retrospective (2015, Justus Bier Award for Curators), the exhibition Rochelle Feinstein: I Made a Terrible Mistake (2016, AICA Germany Award “Special Exhibition”), the film series Normalzustand. Underground Film Between Punk and Art Academy (2017), as well as After the Fact. Propaganda in the $21^{\text {st }}$ Century (2017), an exhibition and events project probing the dialectical relationship between current Western propaganda and art. 
Luis Velasco-Pufleau is a musicologist and electroacoustic music composer. He is currently a postdoctoral researcher at the University of Fribourg and associated research fellow at the Fondation Maison des sciences de l'homme in Paris (Humanitarian studies platform and ANR research programme Sortir de la violence). His research focuses on political, historical, and aesthetics issues of music and sound, in particular related to conflict and violence. After completing his Ph.D. in Music and musicology at Sorbonne University in 2011, he was a postdoctoral researcher at the École des Hautes Études en Sciences Sociales (EHESS), and University of Salzburg, as well as a Balzan visiting fellow at the University of Oxford. He is an editorial board member of the journal Transposition, Music and Social Sciences and editor of the open access research blog Music, Sound and Conflict.

\section{References}

Badiou, Alain. (2002 [1993]) Ethics: An Essay of the Understanding of Evil. London: Verso.

Boltanski, Luc. (1999 [1993]) Distant Suffering: Morality, Media, and Politics. Cambridge: Cambridge University Press.

Chouliaraki, Lilie. (2013) The Ironic Spectator: Solidarity in the Age of Post-Humanitarianism. Cambridge: Polity.

Foucault, Michel. (1980 [1977]) The Confession of the Flesh. In Power/Knowledge: Selected Interviews and Other Writings, 1972-1977, ed. Colin Gordon, 194-228, New York, NY: Pantheon Books.

Fraser, Nancy. (2008) Abnormal Justice. Critical Inquiry 34 (3): 393-422. <https:// doi.org/10.1086/589478>

Jeffries, Stuart. (2014) Band Aid 30 introduces a whole new world of dread and fear. The Guardian. <https://www.theguardian.com/music/2014/nov/17/band-aid-30new-world-dread-and-fear-deconstruction-lyrics > (Accessed 13 August 2018).

Rancière, Jacques. (2013) The Ethical Turn of Aesthetics and Politics. In Dissensus: On Politics and Aesthetics, 184-202, London: Bloomsbury Academic.

Velasco Pufleau, Luis. (2013) Chansons humanitaires, dépolitisation des conflits et moralisation des relations internationales à la fin de la Guerre froide. Relations Internationales (156): 109-123. <https://dx.doi.org/10.3917/ri.156.0109>

(2014) Reflections on Music and Propaganda. Contemporary Aesthetics 12. <https://hdl.handle.net/2027/spo.7523862.0012.007> (Accessed 13 August 2018). 
(2017) Betrachtungen zu Musik und Propaganda. In After the Fact. Propaganda in the $21^{\text {st }}$ Century, eds. Stephanie Weber and Matthias Mühling, 409-449, Munich: Lenbachhaus.

Velasco-Pufleau, Luis and Sergio Santamaría Borges. (2017) Reflections on Music and Propaganda, Städtische Galerie im Lenbachhaus und Kunstbau München. <https:// youtu.be/23yinuDCeH4> (Accessed 13 August 2018).

Weber, Stephanie and Matthias Mühling (eds.). (2017) After the Fact. Propaganda in the $21^{\text {st }}$ Century, Munich: Lenbachhaus. 